\title{
THE IMPACT OF FATIGUE ON JUMP SHOT HEIGHT AND ACCURACY OVER A LONGER SHOOTING DISTANCE IN BASKETBALL
}

\author{
Frane Erčulj, Matej Supej \\ University of Ljubljana, Ljubljana, Slovenia
}

\begin{abstract}
Frane Erčulj. Associate Professor at the University of Ljubljana, Slovenia, member of European College of Sport Science. The field of
\end{abstract} scientific research - coaching and sports performance, conditioning, tactics and techniques of basketball.

\begin{abstract}
This study basically aimed to establish how a gradual increase in effort (fatigue) affects the jump height and accuracy of shots at the basket.

For this purpose, an elite basketball player, Primož Brezec, performed seven series of 20 shots from a distance of 7.24 metres. All shots were executed in four-second intervals and the height of each jump shot was measured. The accuracy of shots was established on the basis of the number of goals and distance from the centre of the ball to the centre of the rim of the basket. Thus, for each shot a kinematic analysis was applied using the APAS system to calculate the parabolas of ball flight and the distance between the two points mentioned. During an individual series of shots the subject player performed a special basketball motor task consisting of running, a defensive slide and jumps. The effort gradually increased with each motor task and, in the meantime, the subject's heart rate and concentration of lactates in his blood were measured.
\end{abstract}

The results of the study show that the jump height decreases on average with each series of shots (with the exception of series two) and that the differences between the series are statistically significant $(p<0.01)$.

There were no statistically significant differences between the individual series of shots in terms of shooting accuracy and / or number of goals. The number of goals decreased drastically in the last series, $i$. e. in the conditions of maximum fatigue (heart rate: 197 beats / min, lactate concentration: $9.7 \mathrm{mmol} / \mathrm{l}$ ).

The average distance between the centre of the ball and the centre of the rim in the plane of the rim ranges between 13.5 and $16.6 \mathrm{~cm}$, however, it does not increase with fatigue.

Keywords: jump shot, kinematic analysis, accuracy, jump height, fatigue

\section{INTRODUCTION}

$\mathrm{S}$ ome sports require maximum accuracy when performing motor tasks or shooting at a target, notwithstanding the fatigue caused by intensive and / or long-lasting movements. One such sport is basketball since it is characterised by relatively short and quick movements, fast starts and a great number of stoppages, changes of direction and jumps. To summarise the findings of some authors who have delved into this subject, a basketball player covers a total distance of 5000 to 7000 metres in a $4 \times 10$ minute match, approximately $54 \%$ of which is accounted for by slow running, $40 \%$ by fast running and $6 \%$ by sprinting (Mahorič, 1994; Dežman, Erčulj, 2005). Besides the interruptions between individual parts of the game (a 10- to 15-minute break between the two halves and a two-minute break between the quarters), interruptions also occur during the game due to rule violations, player substitutions and time-outs. Therefore, the game may also be 
divided into two phases, namely, the movement phase (active) and the interruption phase (passive). Usually, their ratio is approximately $1: 1$ (40 minutes of play and 40 minutes of interruptions). However, if the interruptions between individual parts of the game are taken into consideration, the ratio turns in favour of the interruptions (Dežman, Erčulj, 2005).

In more intensive movements players typically use anaerobic alactate or lactate energy, while in less intensive ones aerobic energy is used. Some authors (Brittenham, 1998) postulated that basketball is a $20 \%$ to $25 \%$ aerobic and $75 \%$ to $80 \%$ anaerobic sport activity. The average heart rate of a player during a match is 160 to 168 beats per minute and, excluding the interruptions between parts of the game, even 170 beats per minute and more. The average concentration of lactates in a player's blood during a match is about four $\mathrm{mmol} / 1$ but it may also reach or even exceed eight mmol / 1 (Dežman, Erčulj, 2005).

Modern elite basketball imposes a considerable strain and loading on players and simultaneously requires a high degree of accuracy (Jovanović-Golubović, Jovanović, 2003). The accuracy of shooting at the basket is of particular importance as the circumference of the ball ranges from 75 to $78 \mathrm{~cm}$ while the diameter is about $24 \mathrm{~cm}$. A basket is a horizontal ring with a diameter of $45 \mathrm{~cm}$ which is fastened on a board at the height of $305 \mathrm{~cm}$.

Some authors (e. g., Sherwood et al., 1988) stated that motor accuracy was related to the degree of engagement of muscular force in a functional movement. Hence, muscular strength and training for strength positively impact on the accuracy of execution of a variety of movements. Among others, T. J. Carrol et al. (2001) confirmed the above, also claiming that this impact primarily manifests itself in decreased variability in the amplitude and time dimension of muscular activity. Kauranen et al. (1998) reported that the increase in the strength of the upper extremities improved the co-ordination and velocity of movement but the selection reaction time was shorter. The decrease in net muscular force of agonists may reduce the accuracy of these muscles' functioning.

It may be concluded from the above that muscular strength positively impacts on the accuracy of shooting at the basket, which has also been confirmed by Justin et al. (2006). They established that training for maximum strength of the elbow extensors improved the accuracy of three-point shooting, while this was not the case for tasks where minimal muscular force was applied (e.g. the throwing of darts). An individual with better developed strength will invest less muscular force into the movement of shooting at the basket compared to an individual with less developed strength. It often happens that when shooting at the basket players with less developed strength activate some additional muscles as well, which may bring about some modifications to the shooting technique. This is particularly true for shooting over a longer distance and in conditions of fatigue when one is able to engage less muscular force (Justin et al., 2006).

Accuracy is of course even more important when shooting over a longer distance and the impact of fatigue on the shooting accuracy is probably even stronger. Shots made from behind the semi-circular line which is $6.25 \mathrm{~m}$ (in the NBA even $7.24 \mathrm{~m}$ ) in distance from the projection of the centre of the rim on the floor score three points - not just two like ordinary shots made from field.

Shooting accuracy in basketball is also influenced by other factors besides fatigue. Hudson (1982) arrived at the following conclusions in relation to the accuracy of free-throw shooting in basketball:

- accuracy (percentage of successful shots) is related to higher skill;

- greater stability (i. e., a balanced centre of gravity and vertical trunk inclination) is related to enhanced skill;

- a better ratio of the height of release to the standing height is related to higher skill; and

- the angle and velocity of projection, taken independently, are not related to the skill level.

F. J. Rojas et al. (2000) also established that the shots that are successful or which are missed depend on a set of factors. There is no single projection angle that would yield a perfect shot, however it involves a combination of both the initial launch velocity, the angle of projection, the diameter of the ball as well as the rim (if they are varied). Each factor is more or less dependant on each other to produce a perfect shot.

The aim of this study was to establish how fatigue influenced some characteristics of the jump shot and, in particular, how a gradual increase in strain impacted on the accuracy of shooting 
at the basket over a longer distance and on the jump shot height. Namely, in basketball field shots are usually jump shots. Thus, the height of release increases and the player can throw over the arms of the defence players more easily. In addition, the possibility of the efficient hindering or even blocking of the shot is reduced. This article deals with a very interesting and important issue which has not received much scientific attention in the past even though it is one of the key performance factors in basketball. Namely, in modern elite basketball a player requires highly-developed endurance and functional abilities. The playing situation often requires high strain and / or loading with the lowest possible fatigue of the player. At the same time, the player must be capable of realising and co-ordinating the highest possible level of impetus and accuracy in different movements, irrespective of fatigue, which is particularly the case when shooting at the basket over a longer distance.

\section{METHODS}

The subject of the study was the elite basketball player Primož Brezec, a member of the Slovenian National Team and a successful NBA player for the Charlotte Bobcats. He performed seven series of 20 shots at the basket from the distance of $7.24 \mathrm{~m}$, which according to the NBA league rules constitutes a three-point shot. All shots were executed in four-second intervals while the OptoJump device (Globus, Italy) was used to measure the height of each jump shot. The accuracy of shots was established on the basis of the number of goals and distance from the CB point (centre of the ball) to the CR point (centre of the rim). The kinematic analysis, which was performed in the APAS system, was applied for each shot to model with a parabola the last phase of the ball flight and to find its intersection on the plane of the rim. In the event the ball did not go through the basket the parabola was extrapolated. Then the absolute distance between the $\mathrm{CB}$ and the $\mathrm{CR}$ points was calculated. The subject performed a special basketball motor task between individual series of shots, consisting of running, defensive slides and jumps. In each subsequent motor task the loading was gradually increased and the subject's heart rate measured, while his blood lactate concentration was measured after the loading and before each shooting series.
To facilitate the understanding and evaluation of the results the sample of variables also included some basic measures of the subject's morphological characteristics.

The data was processed with the SPSS statistical software package. A comparison of the data was made and differences between the series of shots established using descriptive statistics and a one-way analysis of variance.

\section{RESULTS}

The study was performed on a subject with some extremely pronounced morphological characteristics. These may impact significantly on the results relating to overcoming strain (fatigue) and shooting at the basket and may help us understand and evaluate them better. Therefore, a selection of the subject's main morphological characteristics is presented below.

Despite the fact that this basketball player is extremely tall, it may be established that the ectomorphic component of his somatotype is not extremely pronounced. Slightly higher values of the endomorphic component and percentage of fat mass are probably a corollary of the one month of the subject's inactivity prior to the measurement because of an injury and the end of the competition season in the NBA League. On the other hand, a higher body mass may positively affect the playing performance of this subject who, as a classic centre, moves a considerable amount of the time within a small and condensed space under the basket, often in close contact with the opponents. In the context of the study information on the subject's muscle mass is also relevant. Namely, it may be concluded from it that the subject's muscular strength is well developed and may positively influence his precision when shooting at a basket over a longer distance (Justin et al., 2006).

The results in Table 2 show that the height of a jump decreases on average with each series of shots (with the exception of series two) and that the differences between the series are statistically significant $(\mathrm{p}<0.01)$.

There were no statistically significant differences between the individual series of shots in terms of shooting accuracy and / or number of goals. The number of goals decreased drastically only in the last series, i. e. in the conditions of maximum fatigue (heart rate: 197 beats / min, lactate 
Table 1. Selected morphological characteristics of the subject

\begin{tabular}{|l|l|c|c|}
\hline \multicolumn{1}{|c|}{ Code } & \multicolumn{1}{|c|}{ Name } & Unit & Result \\
\hline Morphology & Morphological characteristics & & \\
\hline 一BH & Body height & $\mathrm{cm}$ & 215 \\
\hline -BM & Body mass & $\mathrm{kg}$ & 123 \\
\hline -Indexes & Indexes & $\%$ & 12.8 \\
\hline -AMASPP & \% of fat (index average) & $\%$ & 57.3 \\
\hline -AMISP & \% of muscle mass (Matiegka) & $\%$ & 18.6 \\
\hline -AKOSP & \% of bone mass (Matiegka) & $\mathrm{m}^{2}$ & 2.72 \\
\hline -ATELP & Body surface (Balke) & & \\
\hline -Somatotype & Somatotype & & 3.1 \\
\hline -AEKTO & Ectomorphic component & & 3.8 \\
\hline -AMEZO & Mesomorphic component & & 3.4 \\
\hline -AENDO & Endomorphic component & & \\
\hline
\end{tabular}

Table 2. Descriptives and Oneway ANOVA

Note. HRRun — average heart rate during a special basketball motor task (no. of beats / $\mathrm{min}$ ); HRShot - average heart rate while shooting at the basket (no. of beats / $\min$ ); La - concentration of lactates in the blood after the end of the motor task and before the series of shots at the basket (mmol/ 1 of blood); JumpH - jump height, established by the OptoJump device (cm); shot T/G - number of throws / number of goals; $\mathrm{CB}$ $\mathrm{CR}$ - absolute distance between the centre of the ball and the centre of the rim in the plane of the rim in $\mathrm{cm}$ (absolute distance of the ball's penetration from the centre of the rim in the plane of the rim) $(\mathrm{cm})$.

\begin{tabular}{|c|c|c|c|c|c|c|}
\hline & HRRun & HRShot & $\mathrm{La}$ & JumpH & $\operatorname{shot} \mathrm{T} / \mathrm{G}$ & $\mathrm{CB}-\mathrm{CR}$ \\
\hline \multirow[t]{2}{*}{ Series 1 (mean / SD) } & 173.854 & 149.023 & 0.8 & 11.335 & $20 / 9$ & 13.539 \\
\hline & 8.934 & 11.705 & & .742 & & 6.137 \\
\hline \multirow[t]{2}{*}{ Series 2 (mean / SD) } & 185.467 & 180.244 & 2.1 & 12.020 & $20 / 10$ & 16.604 \\
\hline & 4.885 & 2.639 & & .869 & & 11.336 \\
\hline \multirow[t]{2}{*}{ Series 3 (mean / SD) } & 189.031 & 186.256 & 3.9 & 11.735 & $20 / 9$ & 15.089 \\
\hline & 4.326 & 1.515 & & .831 & & 12.250 \\
\hline \multirow[t]{2}{*}{ Series 4 (mean / SD) } & 195.283 & 192.971 & 4.5 & 10.605 & $20 / 8$ & 15.436 \\
\hline & 6.028 & 2.872 & & .991 & & 9.465 \\
\hline \multirow[t]{2}{*}{ Series 5 (mean / SD) } & 197.244 & 196.603 & 6.2 & 9.990 & $20 / 12$ & 13.726 \\
\hline & 4.209 & 2.760 & & 1.205 & & 9.412 \\
\hline \multirow[t]{2}{*}{ Series 6 (mean / SD) } & 198.604 & 197.522 & 8.1 & 9.450 & $20 / 8$ & 15.595 \\
\hline & 2.337 & 1.855 & & 1.459 & & 9.843 \\
\hline \multirow[t]{2}{*}{ Series 7 (mean / SD) } & & 197.617 & 9.7 & 8.740 & $20 / 6$ & 14.560 \\
\hline & & 1.999 & & 1.203 & & 8.141 \\
\hline \multirow[t]{2}{*}{ Total (mean / SD) } & 189.944 & 185.742 & 5.0 & 10.554 & $140 / 62$ & 14.936 \\
\hline & 10.378 & 17.119 & & 1.545 & & 9.534 \\
\hline $\mathrm{F}$ & 192.531 & 374.343 & & 26.167 & .690 & .250 \\
\hline F (sig.) & .000 & .000 & & .000 & .658 & .959 \\
\hline
\end{tabular}

concentration: $9.7 \mathrm{mmol} / 1)$. The average distance between the $\mathrm{CB}$ point and the CR point (absolute distance of the ball's penetration from the centre of the rim) ranges between $13.5 \mathrm{~cm}$ and $16.6 \mathrm{~cm}$, however, it does not increase with fatigue.

Figure 1 shows the absolute distance of the ball from the centre of the rim (basket), i. e. the vector sum of the longitudinal and transversal distances at the point where the trajectory of the ball crosses the plane of the rim for each series of shots. It may be established that the average absolute distances in the different series are very similar and with a $95 \%$ confidence interval the medians do not differ. What differs is the width of the $95 \%$ confidence interval of the median and the width of the distribution. Some missed shots deviate more evidently i. e. outliers, however, they occur in almost every series.

\section{DISCUSSION}

The results of the study (Table 2) show that the height of the jump while shooting at the basket is very low on average and usually decreases with each series of shots. In our opinion, such a low jump height is not due to the subject's poorly developed take-off power or jumping ability. It is more likely that, owing to such extreme body height and arm length, the subject's height of ball release is also high, even when the jump is low or there is no jump at all. In basketball, very tall players shoot at the basket over a longer distance less frequently, but when they decide to do this, they are often unobstructed or only obstructed by a shorter defence player. Consequently, in play there is no need for these players to use a high jump when shooting at the basket over a longer distance. 


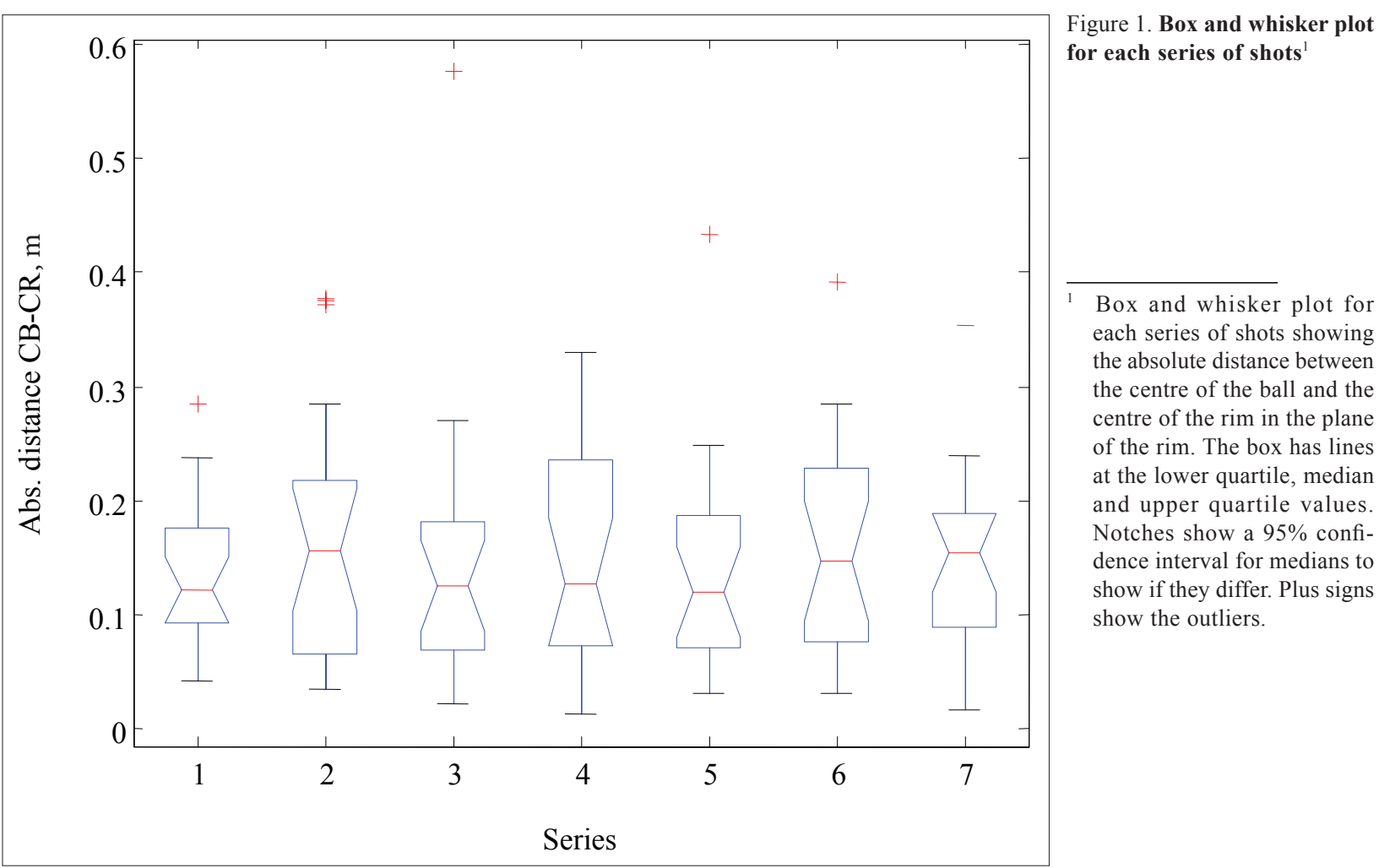

Moreover, it is worth stressing that shots from a very large distance (including the shots executed by the subject in our study) are very demanding and complex in terms of muscular co-ordination and strength. Therefore, the low values of jump height established in our study are not surprising, particularly with the knowledge that in this type of shots even shorter players jump lower or they already release the ball in the initial phase of the jump (Miller, Bartlett, 1993; Rojas et al., 2000). According to S. Miller and R. M. Bartlett (1993) both the maximum jump height and the height of the jump at release tended to decrease as shooting distance increased. For short-range shots, release occurred after the peak of the jump, but increasingly prior to the peak as shooting distance increased. Another thing to emphasise is the fact that our subject shot at the basket in non-situational (non-playing) conditions, that means he was unobstructed and relaxed. With reference to the above, it should also be noted that F. J. Rojas et al. (2000) established that players attempted to release the ball more quickly and from a greater height when confronted by an opponent.

The findings of the study also show that the height of jumps when shooting at the basket drops with increasing fatigue. Table 2 shows that the average jump height in the first three series of shots was approximately the same, while it star- ted decreasing visibly after the third series. In the fourth series of shots the fatigue was obviously so pronounced (heart rate: 192 beats / min, lactate concentration: $4.5 \mathrm{mmol} / \mathrm{l}$ ) that it affected the height of the jumps. In the subsequent series of shots, fatigue gradually increased as a consequence of the higher loading with the special basketball motor tasks, and thus the average height of the jumps in each of the following series of shots was lower. In the conditions of maximum fatigue (heart rate: 197 beats / min, lactate concentration: $9.7 \mathrm{mmol} / \mathrm{l}$ ) the jump height only slightly exceeded eight $\mathrm{cm}$ on average. One of our future studies will try to find out how much the height of the ball release point, which does not only depend on the jump height, decreases due to the above. It is possible that, owing to fatigue, the position of the ball in a throw changed and/or the subject held the ball lower than usual. This would even further lower the point at which the ball was released.

As regards the shooting accuracy, it may be established that fatigue does not play such an important role as in jump height. The number of goals in the first six series ranged from 8 to 12 and only in the last series, i. e. in conditions of maximum fatigue (heart rate: 197 beats / min, lactate concentration: $9.7 \mathrm{mmol} / 1$ ), it dropped to six. It is obvious that the subject found mechanisms for preserving his accuracy despite the 
great fatigue. It would be interesting to ascertain whether he succeeded in this also by changing (adapting) his shooting technique. By all means, the ability to maintain accuracy despite great fatigue is very important and, in our case, it shows that the subject is truly an elite basketball player. This ability may come in handy in play, especially at the end of a match when fatigue increases. It is these moments that determine the winner of a match and any team with several players similar to our subject undoubtedly has an advantage over other teams.

In our case, an even more objective and sensitive criterion for accuracy is the absolute distance of the ball's penetration from the centre of the rim. It may be established that, in all shots, the average distance of the centre of the ball from the centre of the rim in the plane of the rim was slightly less than $15 \mathrm{~cm}$ (Table 1 and Table 2). In other words, the subject missed the centre of the rim by $15 \mathrm{~cm}$ on average. This distance cannot be used as a criterion of accuracy since the velocity of the ball and the angle of incidence - which may be only slightly over $40^{\circ}$ when shooting from such a distance (Rojas et al., 2000; Miller, Bartlett, 1993; Jovanović-Golubović, Jovanović, 2003) - makes it very difficult to hit the centre of the rim. Therefore, a certain longitudinal shift towards the front is perceived at the point of the ball's penetration of the basket. This may even be $10 \mathrm{~cm}$ long or more but the shot will not be too long and the ball will still hit the basket. These contentions are additionally confirmed by Figure 1 that indisputably shows that the lowest values are several centimetres from the centre of the rim, while the lowest quartile reaches about seven to eight $\mathrm{cm}$ in all series. The smallest absolute distance of the ball's penetration from the centre of the rim was recorded in the seventh, last series $(\mathrm{CB}-\mathrm{CR}=1.2 \mathrm{~cm})$ when the shooter was the least efficient and scored only 6 shots. In this series the absolute average distance is below average. The second smallest distance was recorded in the fourth series $(\mathrm{CB}-\mathrm{CR}=1.6 \mathrm{~cm})$, when the subject was below-averagely efficient and scored with 8 from 20 shots. In the fifth series when his performance was best, he came closest to the centre of the basket with the 18th shot $(\mathrm{CB}-\mathrm{CR}=3.1 \mathrm{~cm})$. In this series second smallest average absolute distance CB-CR was recorded. It may thus be established that the values of absolute distance of the ball's penetration from the centre of the rim are not always congruent with the number of goals. This is somewhat logical as absolute accuracy does not count for a goal, it only counts whether the ball goes into the basket or not. Absolute accuracy would only find an expression in a very large number of repetitions. It is also possible that one of the missed shots (or even several) was very inaccurate and / or that in one or several missed shots a very large distance occurred but was still insufficient to be recognised as an outlier, which may significantly affect the average values.

\section{CONCLUSIONS}

To conclude, we wish to reiterate that the study results show that fatigue impacts on the height of a jump when shooting at the basket, the height of a jump decreases on average with each subsequent series of shots (with the exception of series two) and that the differences between the series are statistically significant $(\mathrm{p}<0.01)$.

There are no statistically significant differences between the individual series of shots in terms of shooting accuracy and / or number of goals. The number of goals decreases drastically only in the last series, i. e. in the conditions of maximum fatigue (heart rate: 197 beats / min, lactate concentration: $9.7 \mathrm{mmol} / 1$ ). The average distance between the $\mathrm{CB}$ point and the CR point (absolute distance of the ball's penetration from the centre of the rim) ranges between $13.5 \mathrm{~cm}$ and $16.6 \mathrm{~cm}$, however, it does not increase statistically significantly with fatigue.

Despite the fact that this study did not reveal any significant decrease in the shooting accuracy as a result of fatigue (except under conditions of maximum fatigue), it may be established that fatigue does impact on some of the characteristics of jump shot over a longer distance. The impact of fatigue is mostly reflected in the height of a jump which is one of the key factors of the height of ball release. In the future we would like to establish whether and how fatigue impacts on some other kinematic parameters of the shot which were not dealt with in this study (e. g. velocity, angle and height of ball release, longitudinal shift and angle of penetration of the ball in the basket). Most of all, it would be interesting to find out whether fatigue causes quantitative and qualitative changes in the shooting technique, and to analyse these changes. 


\title{
REFERENCES
}

Brittenham, G. (1996). Complete Conditioning for Basketball. New York: Human Kinetics.

Carroll, T. J., Carson, R. G., Riek, S. (2001). Neural adaptations to resistance training. Implications for movement control. Sports Medicine, 31 (12), 829-840.

Dežman, B., Erčulj, F. (2005). Kondicijska priprava v košarki (Conditioning for Basketball). Ljubljana: Faculty of Sport, Institute of Sport.

Hudson, J. L. (1982). A biomechanical analysis by skill level of free throw shooting in basketball. In J. Terauds (ed.), Biomechanics in Sports (pp. 95-102). Del Mar, CA: Academic Publishers.

Jovanović-Golubović, D., Jovanović, I. (2003). Antropološke osnove košarke (Anthropological Basics of Basketball). Niš: University of Niš, Faculty of Physical Culture.

Justin, I., Strojnik, V., Šarabon, N. (2002). Vpliv povečanja maksimalne moči iztegovalk komolca na sposobnost natančnega zadevanja pri metu pikada in metu za tri točke v košarki (Impact of increased maximum strength of elbow extensors on the precision of dart throws and three-point basketball shots). Šport, 2, $5-55$.
Kauranen, K. J., Siira, P. T., Vanharanta, H. V. (1998). A 10-week strength training program: Effect on the motor performance of an unimpaired upper extremity. Arch Phys Med Rehabil, 79 (8), 925-30.

Mahorič, T. (1994). Zunanje in notranje obremenitve beka na košarkarski tekmi (Internal and External Loadings of a Guard on Basketball Match). Ljubljana: Faculty of Sport.

Miller, S., Bartlett, R. M. (1993). The effects of increased shooting distance in the basketball jump shot. Journal of Sport Sciences, 11, 28-293.

Miller, S., Bartlett, R. M. (1996). The relationship between basketball shooting kinematics, distance and playing position. Journal of Sport Sciences, 14, 243-253.

Rojas, F. J., Cepero, M., Onä, A., Gutierrez, M. (2000). Kinematic adjustments in the basketball jump shot against an opponent. Ergonomics, 2000, Vol. 43, 10, $1651-1660$

Sherwood, D. E., Schmidt, R. A. \& Walter, C. B. (1988). The Force / Force Variability Relationship under Controlled Temporal Conditions. Journal of Motor Behaviour, 20, 106-116.

\section{NUOVARGIO POVEIKIS KREPŠININKO ŠUOLIO AUKŠČIUI IR METIMO İ KREPŠI IŠ TOLI TIKSLUMUI}

\author{
Frane Erčulj, Matej Supej \\ Liublianos universitetas, Liubliana, Slovenija
}

\section{SANTRAUKA}

Tyrimo tikslas — nustatyti, kaip pamažu didèjantis nuovargis veikia krepšininko šuolio aukštị ir metimu tikslumą.

Tyrimo metu didelio meistriškumo krepšininkas Primož Brezec atliko septynias serijas metimų iš 7,24 m atstumo. Kiekvienas metimas turèjo būti atliekamas per $4 \mathrm{~s}$, krepšininko šuolio aukštis pamatuojamas. Metimu tikslumas vertintas pagal tikslių metimų skaičių ir ỉkritusio kamuolio svorio centro atstumą nuo lanko. Todèl atliekant kiekvieno metimo kinematinę analizę buvo naudojama APAS sistema, kuri leidžia apskaičiuoti kamuolio skriejimo parabolę ir atstumą tarp minètų taškų. Kiekvienos metimo serijos metu tiriamasis atlikdavo specialias judejjimo užduotis (bẻgimo, gynybos veiksmų imitavimo judant į šalis pristatomuoju žingsniu, šuolius). Laktato koncentracija kraujyje buvo matuojama atliekant užduotis ir pertraukų metu.

Tyrimo rezultatai parodè, kad vidutinis krepšininko pašokimo aukštis mažèjo su kiekviena metimų serija (išskyrus antrą seriją), ir šis mažèjimas buvo statistiškai patikimas $(p<0,01)$. Nebuvo nustatyta statistiškai patikimo tikslumo skirtumo tarp metimų serijų (tikslių metimų skaičiaus). Tikslių metimų skaičius smarkiai sumažejo paskutinių metimo serijų metu, t. y. esant maksimalaus nuovargio būsenai (širdies susitraukimu dažnis - 197 tv. / min, laktato koncentracija kraujyje - 9,7 mmol / 1). Vidutinis atstumas nuo kamuolio svorio centro iki krepšio lanko svyravo nuo 13,5 iki $16.6 \mathrm{~cm}$ ir didejjant nuovargiui nekito.

Raktažodžiai: pašokimas, kinematinė analizè, tikslumas, šuolio aukštis, nuovargis.

Gauta 2006 m. rugpjūčio 25 d.

Received on August 25, 2006

Priimta 2006 m. gruodžio $6 \mathrm{~d}$.

Accepted on December 6, 2006
Frane Erčulj

University of Ljubljana

(liublianos universitetas)

Gortanova 22, 1000 Ljubljana

Slovenia (Slovėnija)

Phone +38615207766

E-mail frane.erculj@fsp.uni-lj.si 